\title{
Retirement Village for Malay Muslims
}

\author{
Noor Hanita Abdul Majid, Mohd Hazwan Hamidi, Zuraini Denan \\ Kulliyyah of Architecture and Environmental Design, \\ International Islamic University Malaysia, Malaysia \\ * hanita@iium.edu.my
}

\begin{abstract}
The growing elderly population indicated a shift in cultural context in Malaysia and the needs for elderly care facilities. This paper looks at the cultural sustainability issues and Islamic perspectives requirements through a review on the recommendations outlined in the Quran and Hadiths; surveys and case studies on the available elderly care facilities in Malaysia. The results indicated the perception of the respondents on the idea of having elderly care for Muslim community and also the preferred type of care facilities. The research findings outlined the criteria for a cohesive retirement village for Muslims.

Keywords: retirement village, cultural sustainability, Islamic perspectives

eISSN 2514-751X @ 2018. The Authors. Published for AMER ABRA CE-Bs by e-International Publishing House, Ltd., UK. This is an open-access article under the CC BY-NC-ND license (http:///creativecommons.org/licenses/by$n c-n d / 4.0)$. Peer-review under responsibility of AMER (Association of Malaysian Environment-Behaviour Researchers), ABRA (Association of Behavioural Researchers on Asians) and CE-Bs (Centre for EnvironmentBehaviour Studies), Faculty of Architecture, Planning \& Surveying, Universiti Teknologi MARA, Malaysia.

DOI: https://doi.org/10.21834/aje-bs.v5i17.48
\end{abstract}




\subsection{Introduction}

The growing numbers of the elderly population have caused a shift in the cultural context in Malaysia. The changes are due to the increasing percentage, education level and aspiration of the ageing population. These changes need to be adhered to in ensuring a quality living for this population group in their golden age. Currently, there are provisions for health care facilities, retirement villages, old folk's homes and other facilities of the kind for elderly and retirees that promoted different concepts of facilities; Malaysia as a Second Home, Resort Style Retirement Environment and others that are mainly modeled after retirement facilities overseas. However, due to the local cultural context, Malaysia needs to address the issues and needs of the population to provide a conducive and cohesive environment.

At present, there is an inclination for Muslim retirees to choose the Pondok system to spend their time after retirement. Pondok is an institution for Islamic studies which instills the Islamic spirit and impart religious knowledge that is popular for the Muslim to spend old age to deepened their understanding of Islam. In this manner, the retirees can enhance their knowledge and practice and also keep themselves intellectually stimulated. Pondok institution is an example of the implementation of the Islamic way of life for a retirement facility. The elderly tend to choose and to concentrate their life after working in learning in depth about Islam.

The paper aimed to look into the issues of the ageing population and identify the necessary facilities for the elderly. It is the objective of this paper to deliberate on the contributing factors in stages. Due to the scarcity of elderly care facilities for Muslims and to support cultural sustainability, the research focused on the retirement facilities for Muslims. The paper begins by reviewing the selected elderly care facilities and checking on the compatibility of the existing facilities to the requirements stipulated by the Quran and Hadith. The results are then vetted to the results of the questionnaire survey that validated the facilities as suggested by the conformity analysis.

\subsection{Literature Review}

In Malaysia, a person is eligible for retirement at the age of 56 beginning the year 2001, and recently the retirement age has been extended up to 58 years old by the Public Civil Department. In Malaysia, the population over 50 years of age is considered elderly population or golden citizen and is given privileges in facilities such as travelling fares, admissions and health facilities. The increase in the elderly population is the basic indicator that the provision for future retirees is an issue. The CENSUS results in 2010 reported an increase to $5.1 \%$ from $3.9 \%$ in 2000 the population group above 65 years of age. In addition to the increase in the ageing population the people are also living longer as evidenced by an increase in life expectancy.

The boomer period coincides with the improvement of education level for the population since Malaysia Independence in 1957. The affected group is now at retirement age and mainly involves working class or professionals. Hence, the aspiration of the retirees group has differed from the conditions where more elderly population mostly resides in villages and worked in the rural areas. Currently, the Baby Boomer (born between 1946 and 1965) in Asia 
is a generation of well-educated and affluent people that have a great interest in healthcare and wellness, and retirement homes. The needs and aspiration of these retirees are different and further enhanced by logistic factors. Due to the migration of the population and the education level, the population group at the age of $50+$ has been residing in the urban area and has worked and raised their families there. Instead of returning to the village for retirement, the retirees now prefer to age-in-place close to their children who are raised, worked and also reside in the urban area.

The current cultural context in Malaysia has outlined the children's responsibilities to care for the ageing parents regardless of the race and religion. However due to the economic constraints and demands, most children with ageing parents are committed to working for a living. Hence, many have opted to send their parents to an elderly care center or hire help at home. In Malaysia, the elderly care is provided both by private, NGOs and governmental bodies. The facilities ranged from daily to long term stay with options of packages and facilities. All elderly care centers should adhere to the requirements and standards determined by Care Centre Act (1993) and Care Centre Regulation (1994) to protect the interest of an older person.

Currently, the elderly care centers have more percentages of non-Muslim patrons. Due to religious and cultural guidelines, the Malay Muslims had hesitated to send their ageing parents to the elderly care facilities and care facilities for this group is scarce. The concept of retirement home/ facilities/ villages does not exist since it is the obligation for all Muslim in looking after their parents.
Allah's Apostle (peace be upon him) said:
"Let him be humbled into dust; let him be humbled into dust"
It was said: "Allah's Messenger, who is he?"
He said: "He who sees either of his parents during their old age or he sees both of them, but he does not enter Paradise (neglecting his / her duties towards them)"

(Muslim 6189)

In Islam, serving one's parents is a duty second to prayer, and it is their right to expect it. It is clearly stated in the Surah Al-Isra' (The Journey by Night) in verses 23-24:

Your lord has commanded that you worship none but Him, and that you be kind to your parents. If one of them reaches old age with you, do not say to the word of disrespect, or scold them, but say generous word to them. And act humbly to them in mercy, and say, "My lord, have mercy on them, since they cared for me when I was small."

(Quran, 17:23-24)

There have been researches conducted to analyze the relationship between what has been prescribed in Quran and Hadith to the social conduct and built environment. Mohd Nor and Siti Fatahiyah (2010) discussed how the Quran and Hadith can inculcate a good behavioural attitude towards the environment. On the other hand, Noor Hanita et. al. (2010) analyzed the verses of Quran and the sayings of the Prophet (PBUH) on the needed facilities to comply with the needs of elderly care facilities. Hence, consideration of what has been stipulated in the Quran and Hadith has been considered in suggesting the compatible facilities for the elderly/ retirees. 


\subsection{Methodology}

The research is undertaken in stages to define the cohesive environment needed for cultural sustainability of the elderly. The case studies (first stage) were conducted to review the existing facilities at selected elderly care centres. The research has identified five elderly care facilities that represent government and private elderly care organizations, and Pondok that are learning institutions that are popular for Muslim retirees. The assessment has included elderly facilities in general to gain insights on the existing facilities without discrimination of the race and religion of the patrons. This has led to the assessment of the conformity of the existing facilities to the Islamic guidelines for the care of elderly (second stage). The Islamic guidelines (as specified by Quran and Hadith) are deemed to be necessary for the formulation of cohesive retirement environment that is suitable for the cultural sustainability of the Muslim population.

The data gained on the conformity is than compared to the results of the questionnaire survey conducted on population as described by the CENSUS as the working group between forty (40) to sixty (60) years of age (third stage). The respondents consist of $60 \%$ from the government sector, $29 \%$ from the private sector and $11 \%$ of self-employed individuals. One hundred (100) assisted surveys were administered on 50 males and 50 female respondents. The survey results are important indicators of the needs and aspirations of the future retirees that are needed to provide cohesive retirement facilities for the group.

\subsection{Research Objectives, Methodology and Study Area}

\subsection{Case Studies}

The selected case studies for the review on the elderly facilities are done randomly. The selected case studies are Pondok Pasir Tumbuh (P1), Pondok Lubuk Tapah (P2), and Yayasan Al Jenderami (P3) as representative of the Pondok insitutions. In addition, the case studies also included Rumah Sri Kenangan Cheng (G1) that is a government funded retirement home and Sri Seronok Retirement Village (N1) that is privately owned. The case studies (first stage) will determine the facilities and also the basic information in the retirement home. All selected case studies except N1 have a majority of Muslim patrons.

In general, the selected case studies suggest the important or necessary facilities for retirees. The data gained is from limited number of case studies; nevertheless, it is representative of the two (2) main types of facilities provided for the retirees/ elderly; the Pondok institution and elderly care. The facilities can be grouped into housing, community/ public facilities, leisure facilities, training/ education facilities, health facilities and other supporting facilities. Table 1 indicated in detail the available facilities at the selected case studies. In general, all the case studies have housing and common facilities of various types.

All facilities have independent living accommodation except G1 that also catered for assisted living. In addition, N1 has some guesthouse facilities for visiting family members. Places for worship are provided in all case studies except N1. G1 catered for all races and religion and provided a general place for worship; on the other hand, the Pondok institutions have masjids for congregational prayers and elderly/ retirement homes/village have more 
leisurely and health-oriented facilities due to the basic purpose of their establishments. P1 and P2 are educational institutions that also have patrons of all ages. Alternatively, P3 is established mainly as welfare and learning institution for elderly. Among all, G1 has the most equipped public facilities in line with establishment purpose by the Department of Social Welfare Malaysia.

Table 1: Facilities at Case Studies

\begin{tabular}{|c|c|c|c|c|c|}
\hline FACILITIES & P1 & $\mathrm{P} 2$ & P3 & G1 & $\mathrm{N} 1$ \\
\hline \multicolumn{6}{|l|}{ Housing } \\
\hline Detached/ Self-contained Housing & $\sqrt{ }$ & $\sqrt{ }$ & & & $\sqrt{ }$ \\
\hline Assisted living & & & & $\sqrt{ }$ & \\
\hline Dormitories & $\sqrt{ }$ & $\sqrt{ }$ & $\sqrt{ }$ & & \\
\hline Staff housing & $\sqrt{ }$ & $\sqrt{ }$ & & & \\
\hline Guest House & & & & & $\sqrt{ }$ \\
\hline \multicolumn{6}{|l|}{ Community / Public Facilities } \\
\hline Masjid & $\sqrt{ }$ & $\sqrt{ }$ & $\sqrt{ }$ & & \\
\hline Facilities for worship & & & & $\sqrt{ }$ & \\
\hline Dining Hall & & & & $\sqrt{ }$ & \\
\hline Visiting Area & & & & $\sqrt{ }$ & \\
\hline \multicolumn{6}{|l|}{ Leisure facilities } \\
\hline TV room & & & & $\sqrt{ }$ & \\
\hline Karaoke Room & & & & $\sqrt{ }$ & \\
\hline Sport and recreation facilities & & & & $\sqrt{ }$ & $\sqrt{ }$ \\
\hline Sewing room & & $\sqrt{ }$ & & & \\
\hline \multicolumn{6}{|l|}{ Training / Education Facilities } \\
\hline Community/seminar hall & & $\sqrt{ }$ & $\sqrt{ }$ & & $\sqrt{ }$ \\
\hline Exhibition Hall & & $\sqrt{ }$ & & & \\
\hline Classrooms & $\sqrt{ }$ & $\sqrt{ }$ & $\sqrt{ }$ & & \\
\hline Library & & $\sqrt{ }$ & $\sqrt{ }$ & & \\
\hline Computer facilities & $\sqrt{ }$ & $\sqrt{ }$ & & & \\
\hline \multicolumn{6}{|l|}{ Health facilities } \\
\hline Isolation room and sick bay & & & & $\sqrt{ }$ & \\
\hline Physiotherapy room & & & & $\sqrt{ }$ & \\
\hline \multicolumn{6}{|l|}{ Others } \\
\hline Administration offices & $\sqrt{ }$ & $\sqrt{ }$ & $\sqrt{ }$ & $\sqrt{ }$ & $\sqrt{ }$ \\
\hline Landscape Areas & & & & & $\sqrt{ }$ \\
\hline Public toilets & $\sqrt{ }$ & & & & \\
\hline
\end{tabular}




\subsection{The Islamic Guidelines}

The intention of the review is to identify the facilities available for retirees and to check the conformity of the facilities to cultural sustainability and Islamic guidelines. The review on related Islamic guidelines was undertaken and discussed in Noor Hanita et. al (2010). The Islamic guidelines forwarded comprises of considerations on the physical state or conditions, physical facilities and emotional needs of the elderly. The physical state or conditions is described as physical vitality, mental capacity; the physical facilities are described by sleeping and resting facilities and basic necessity of food and drinks; and, emotional needs is described by mercy and love, elevations of sensitivity and the priority given to women.

The guidelines derived from the Quran verses are assessed against the common facilities outlined in the case studies analysis. Table 2 (second stage) shows the analysis to check the conformity of the facilities to the guidelines.

Table 2: The Conformity of the Existing Facilities to the Islamic Guidelines.

\begin{tabular}{lll}
\hline FACILITIES & ISLAMIC GUIDELINES & \\
\cline { 2 - 3 } & $\begin{array}{l}\text { PHYSICAL STATE/ } \\
\text { CONDITIONS }\end{array}$ & PHYSICAL FACILITIES \\
\hline
\end{tabular}

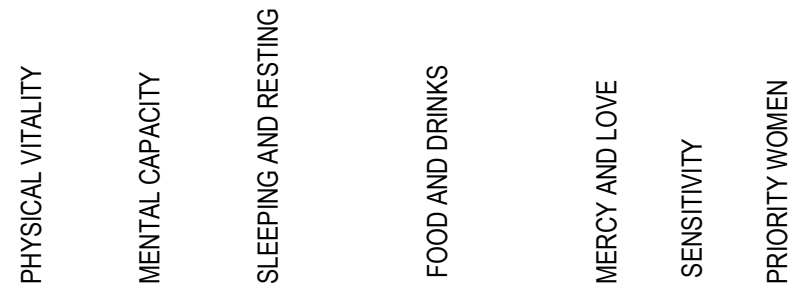

\begin{tabular}{llllllll}
\hline Housing & $\sqrt{ }$ & & $\sqrt{ }$ & $\sqrt{ }$ & & & $\sqrt{ }$ \\
\hline Community/ Public & & $\sqrt{ }$ & & $\sqrt{ }$ & $\sqrt{ }$ & $\sqrt{ }$ & $\sqrt{ }$ \\
\hline Leisure & $\sqrt{ }$ & & $\sqrt{ }$ & & & \\
\hline Training and Education & & $\sqrt{ }$ & & & & \\
\hline Health & $\sqrt{ }$ & $\sqrt{ }$ & $\sqrt{ }$ & $\sqrt{ }$ & $\sqrt{ }$ & \\
\hline
\end{tabular}

Table 2 shows that the facilities provided meet the Islamic guidelines. It also suggested that the facilities are essential since no single facility will fulfill all the guidelines at once. Hence, the retirement villages need to incorporate all facilities to comply with Islamic guidelines. Noor Hanita et. al (2010) forwarded analysis on the Islamic guidelines in the care of elderly through the analysis of Quran and Hadiths. The discussion outlined the emotional status and physical needs of the elderly through excerpts from the religious guidelines. The results of the study indicated a few pertinent factors to consider which will lead to cultural sustainability. 
In addition, the survey aimed to determine the aspirations and the preferred retirement facilities of the respondents. The survey results are distinguished between male and female respondents. The main issues covered are the perception and agreement of the respondents to live in retirement/ elderly care facilities and the preferred living environment. Most respondents ( $51 \%$ male and $46 \%$ female) agreed with the idea of living in a retirement home; specifically, a retirement home for Muslims (Fig. 1). The survey also investigates the respondents' preference on the decision making for the admittance to the retirement facilities (Fig. 2). Most respondents ( $86 \%$ male and $84 \%$ female) agreed that they should make the decision for the admittance to the facilities (Fig. 3). The respondents also feel that the retirement facilities should not be a permanent stay for them and prefer for the facilities to be a transit with the freedom to come and go as they please (Fig. 4).

Q1:I agree with the idea of retirement home for Muslim community

Fig. 1.

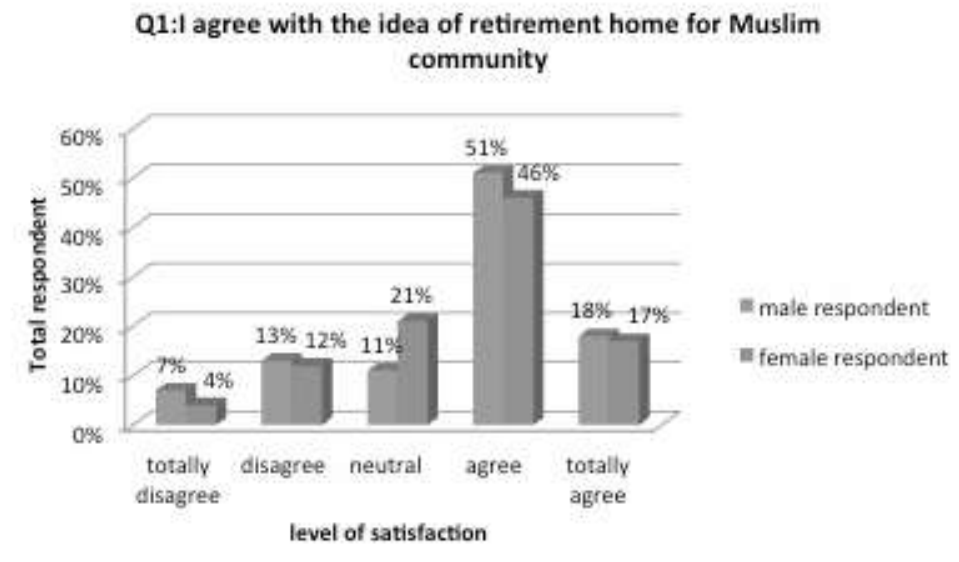

Agreement to the Idea of a Retirement Home

\section{Q2:Retirement home should be designed and established based on the religion and faith basis}

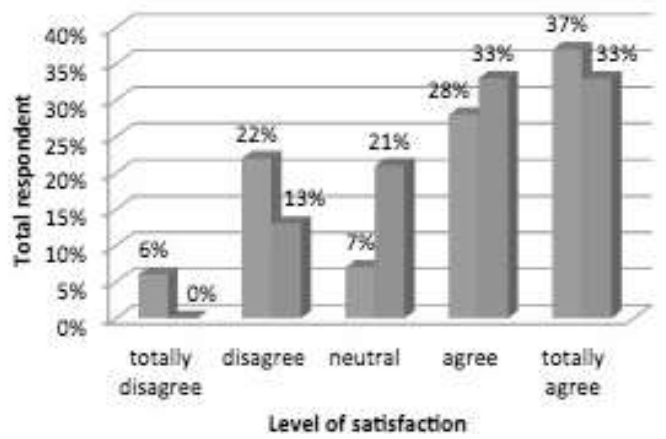

male respondent

il female respondent

Fig. 2. Agreement to the Idea of a Retirement Home Established Based on Religion or Faith 


\section{Q9:The entry to the retirement home must be self admittance}

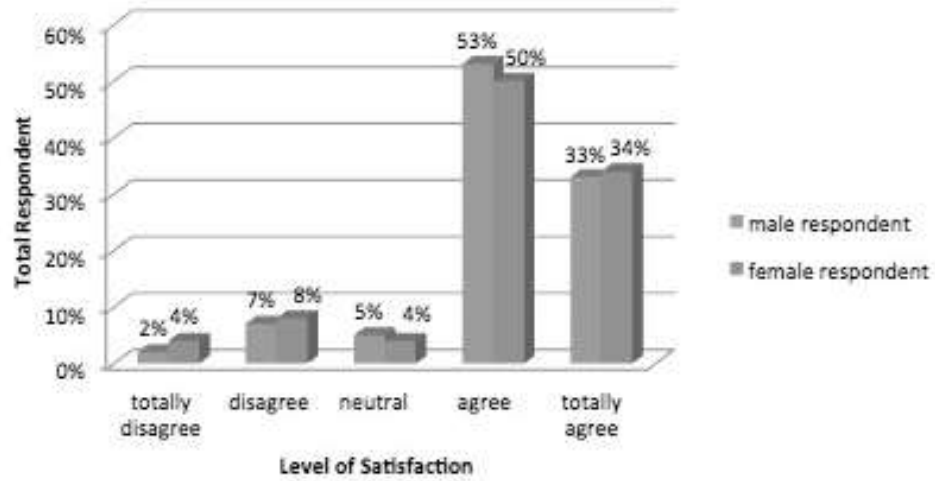

Fig. 3. Decision for Admittance

\section{Q7:Muslim retirement home is just a transit centre only}

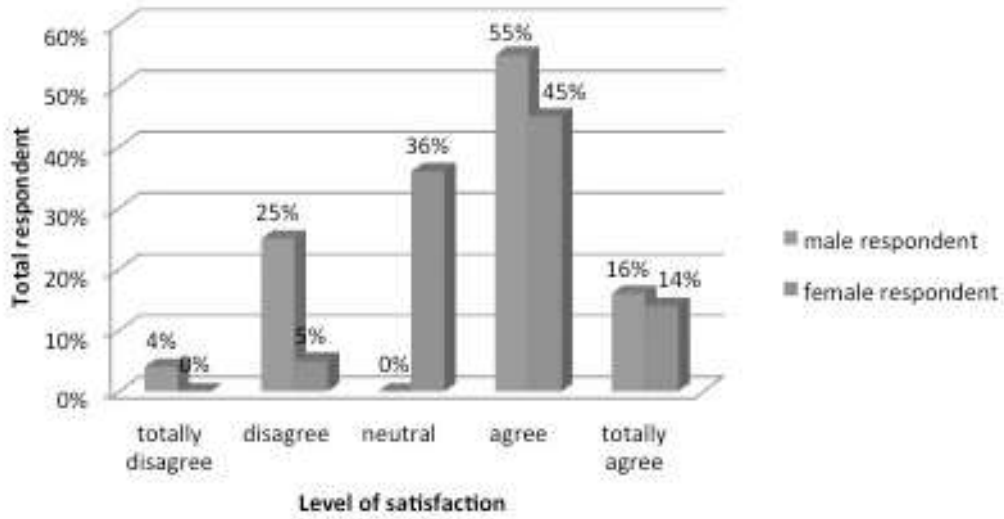

Fig. 4. Permanence of Stay

Table 3 show the conformity of the survey results to the Islamic guidelines. The survey results confirmed that majority of the respondents show desires that are similar to the Islamic guidelines. The villages should include both independent and assisted living to cater for the needs and suits their physical abilities. In cases of independent living, the accommodation needs to be barrier free with specific details that fits the physical requirement of the elderly. 
Abdul Majid, N.H., et.al. / Asian Journal of Environment-Behaviour Studies (ajE-Bs), 3(9) Jul / Aug 2018 (p.137-150)

The environmental design for the retirees also should support the mental capacity of the retirees. Retirees may need a reliable reference to be included in the master planning to assist

Table 3: The Conformity of the Existing facilities to the Islamic Guidelines.

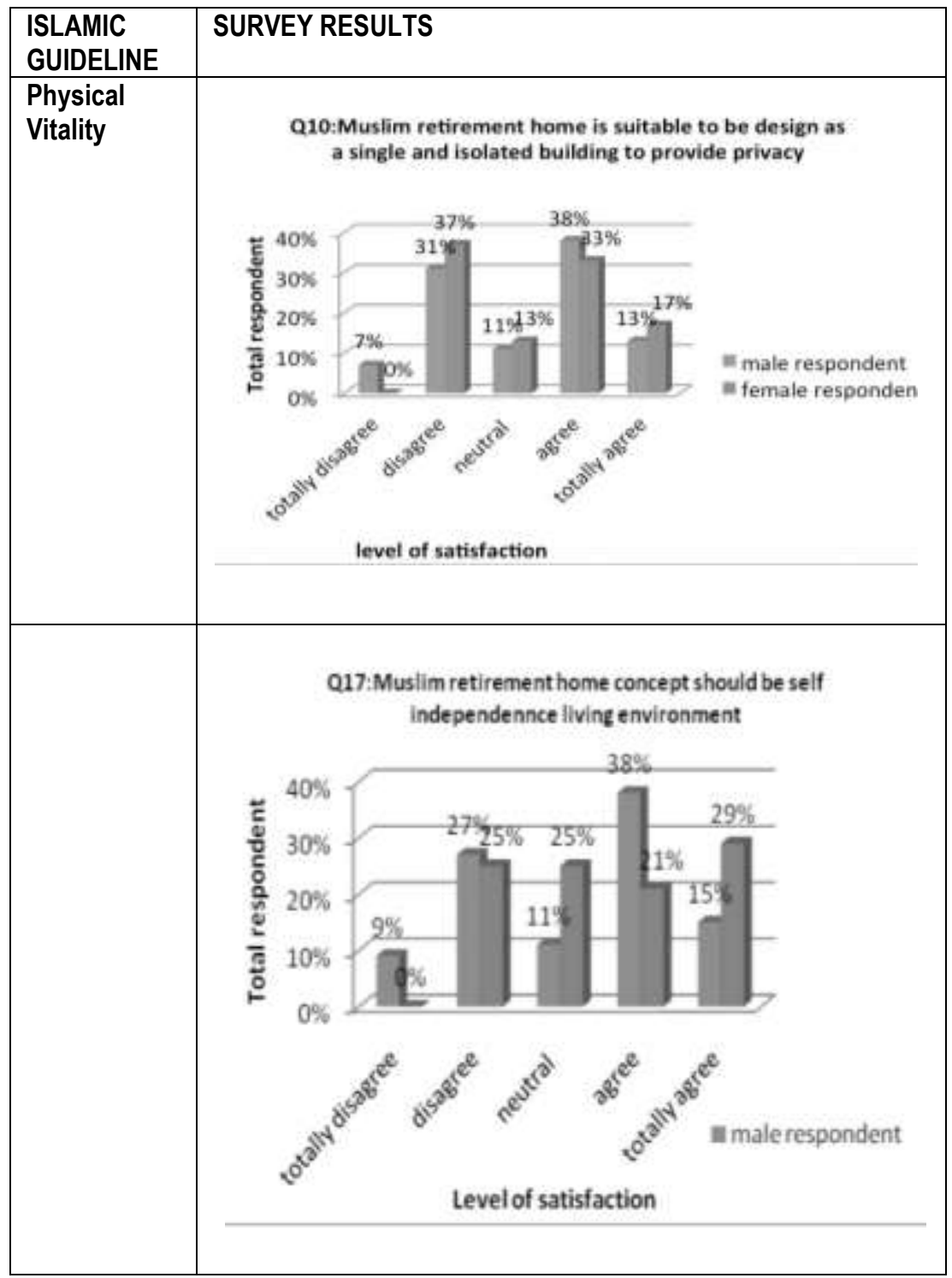




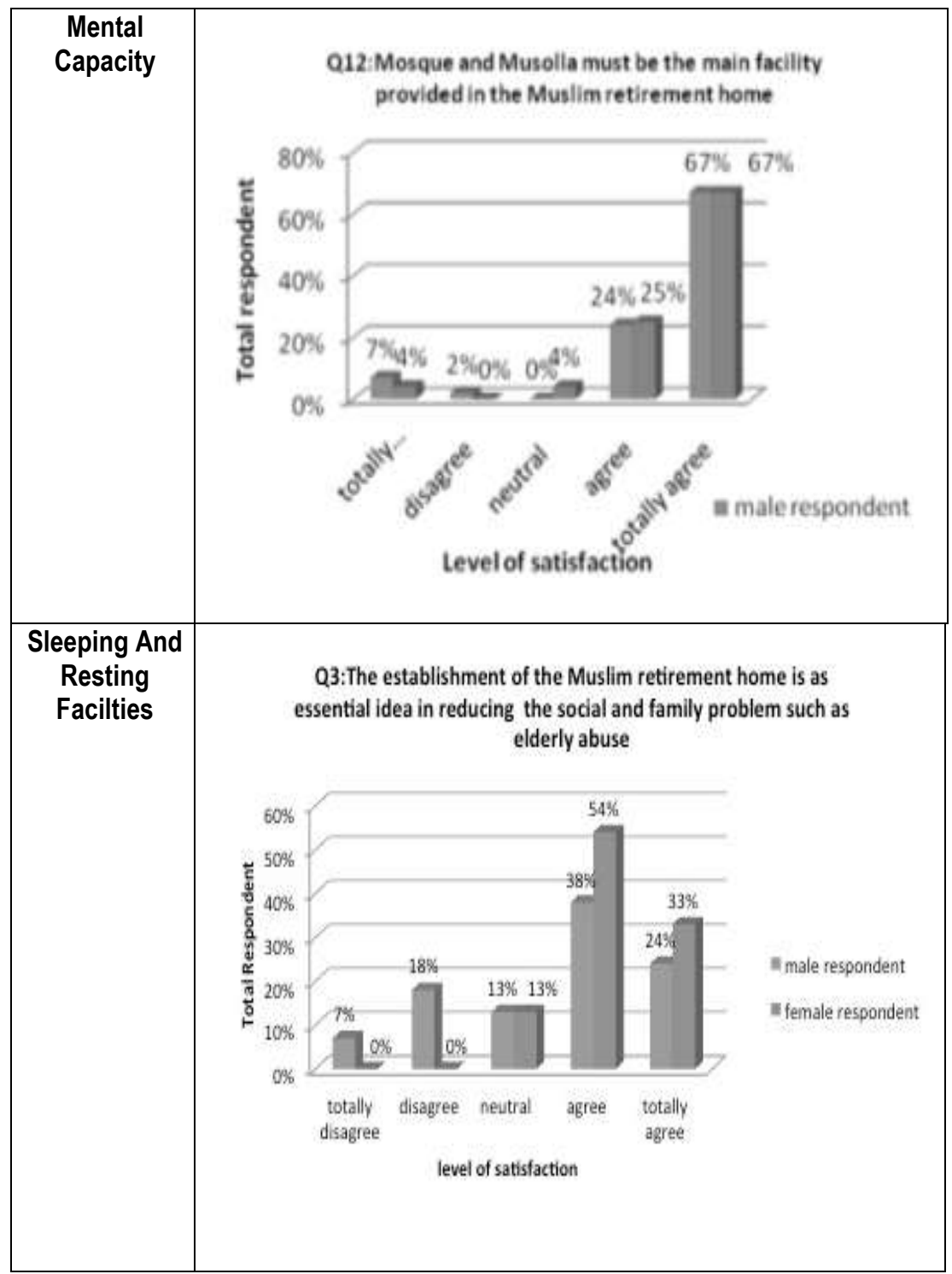


Abdul Majid, N.H., et.al. / Asian Journal of Environment-Behaviour Studies (ajE-Bs), 3(9) Jul / Aug 2018 (p.137-150)

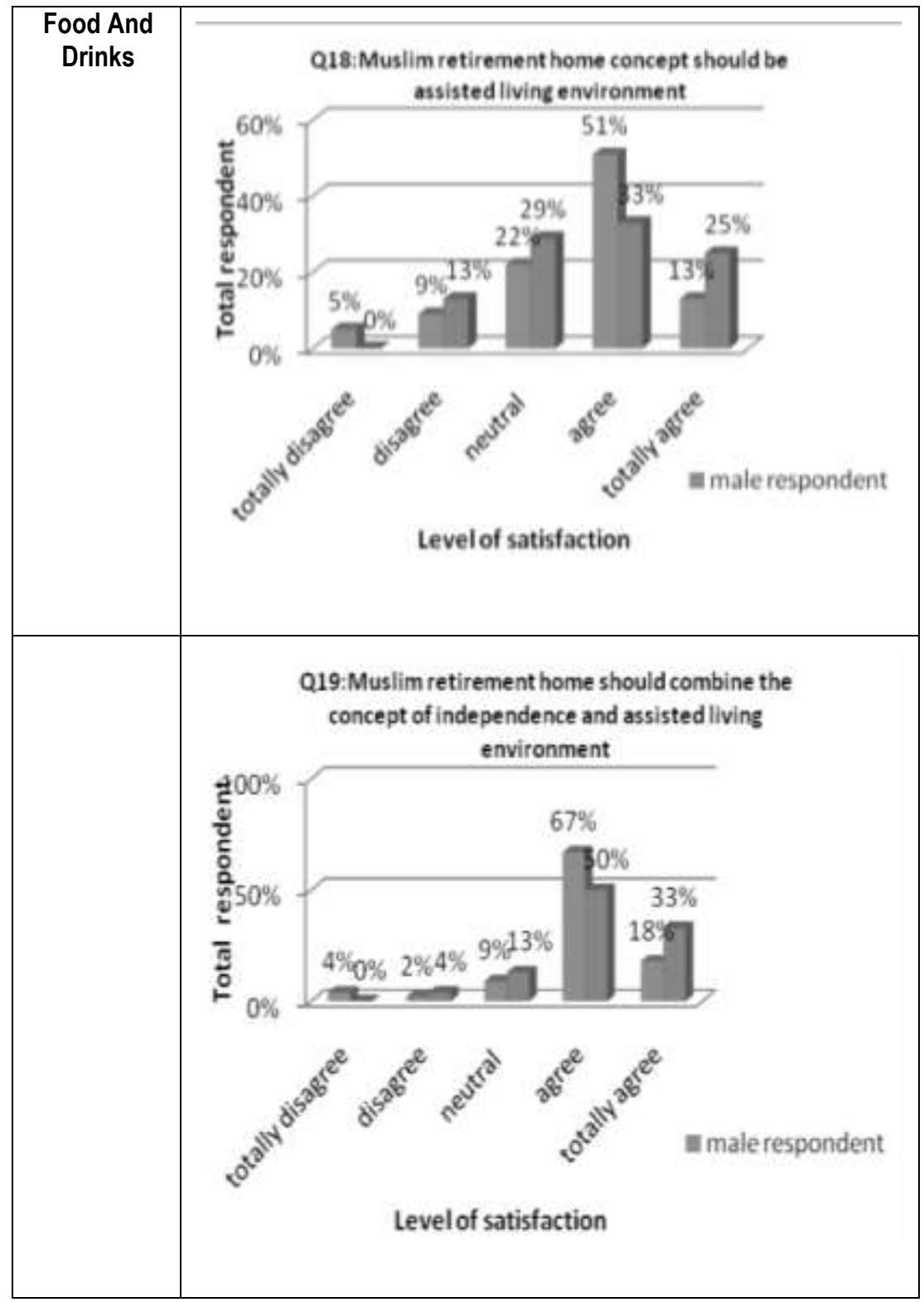


Abdul Majid, N.H., et.al. / Asian Journal of Environment-Behaviour Studies (ajE-Bs), 3(9) Jul / Aug 2018 (p.137-150)

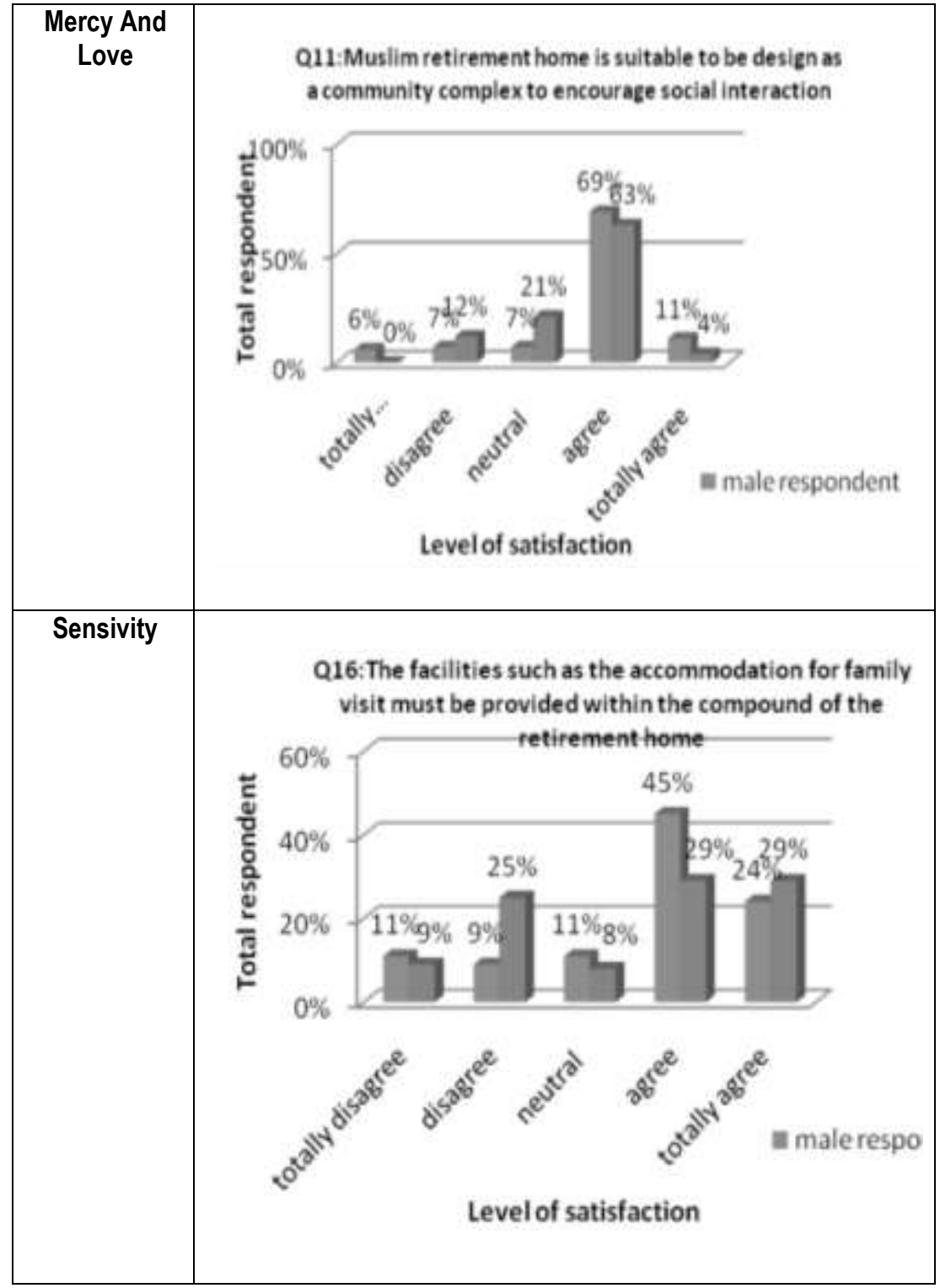




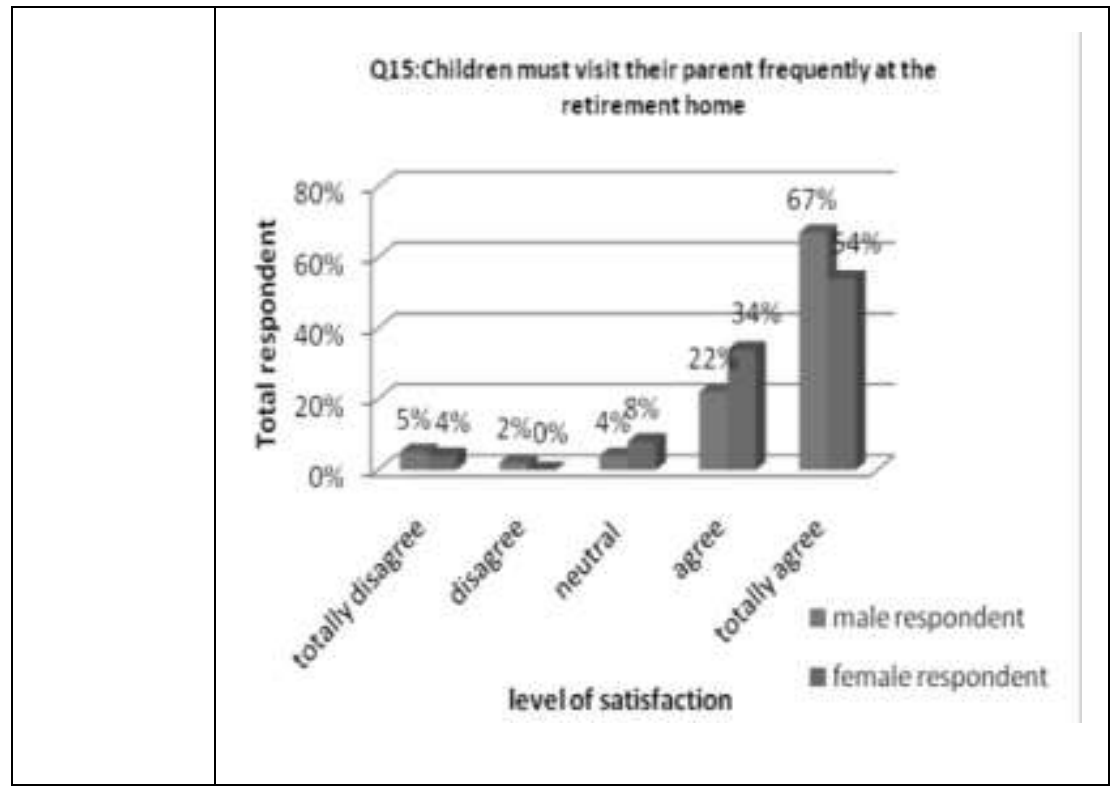

Community and leisure facilities should be included in the retirement villages. There should be a balance of activities for the retirees to be involved in that will accommodate the physical needs for rest and leisure. The community facilities should cater for the basic daily facilities for the elderly for spiritual (masjid), intellectual (classes and community spaces) and physical needs (food and eating facilities). Guests or children accommodations should also be an essential inclusion in the retirement facilities. There should be accommodation for the children to visit or reside in individual homes or guest facilities. This provision is crucial to upholding the Islamic guidelines in the care for elderly.

\subsection{Conclusion}

The establishment of Muslim retirement homes should have a strong fundamental. It has to be a model that meets the cultural and Islamic perspective of Malaysia. Understanding the cultural context and the needs of the population is the key to successful and appropriate facilities for retirement facilities. This research has focused on samples and case studies that cover Pondok, government and private institutions that are familiar as elderly institutions and facilities. Future researches in this area should include these facilities but may include a larger number of samples of respondents and case studies from all over Malaysia. The elderly facilities usually include facilities for orphans that are hypothesized to have a positive impact on the wellbeing of elderly. The social factors and cultural sustainability maybe 
affected by a combined facility for both groups. Future research on how this relationship contributes to the wellbeing of the elderly groups could enhance the quality of life after retirement. This research should be seen as the instigator to future researches and a basis for the formulation of retirement facilities that suits the contemporary needs of the Malaysian population

\section{Acknowledgement}

The authors would like to thank all involved in this research at all stages.

\section{References}

CENSUS 2010. Population Distribution and Basic Demographic Characteristics. Jabatan Perangkaan Malaysia. Population and Housing Census of Malaysia. Department of Statistic Malaysia.

Noor Hanita Abdul Majid, Mohd Hazwan Hamidi and Zuraini Denan (2010). Aesthetic in Search of Appropriate Environment for the Retirees in Malaysia. 30th International Seminar for Public Health Group (PHG) of the Union of International Architects (UIA), KLCC, Kuala Lumpur, Malaysia. 29/11 - 1/12/ 2010.

Mohd Nor, Mamat and Siti Fatahiyah, Mahamood (2010). Islamic Philosophy on Behaviour-based Environmental Attitude. ajE-Bs, Asian Journal of Environment-Behaviour Studies. pp 49-60.

International Law Book Services (1994) Care Centres Act 1993 (Act 506); \& Regulations 1994; Akta Pusat Jagaan 1993 (Akta 506); \& Peraturan-Peraturan. Kuala Lumpur: International Law Book Service. 